\title{
大規模災害後の地域コミュニティの回復に関する研究
}

\author{
宮城県七ヶ浜町の東日本大震災被災地区の地区イベント再開状況から
}

\section{A STUDY ON THE RECOVERY OF LOCAL COMMUNITY AFTER A LARGE DISASTER}

Case study of damaged areas by the Great East Japan Earthquake in Shichigahama Town, Miyagi Prefecture

佃 悠*1, 長谷川 京子*2, 小野田 泰明*3

\section{Haruka TSUKUDA, Kyoko HASEGAWA and Yasuaki ONODA}

\begin{abstract}
The purpose of this paper is to clarify the change of the local community after the damage of the Great East Japan Earthquake and reconstruction projects and the factors for the recovery of the local community by targeting the community associations in Shichigahama Town. The results are following:

1. Each "Tonari-gumi" as a basic unit of community association was reorganized in a different way for each community.

2. There are two type-structure of the community committee. The one remains the pre-modern structure based on the fishery community.

3. The relationship between community committee and event organization is three different types.
\end{abstract}

\section{Keywords: the Great East Japan Earthquake, Local Community, Community Association, Recovery of Community} 東日本大震災，地域コミュニティ，地区組織，コミュニティの回復

\section{1.はじめに}

\section{1. 研究の背景}

2011 年 3 月に発生した東日本大震災とその後の津波は、東北地方 を中心に大きな被害をもたらした。被災地の生活再建に際し、行政 は「地域の再構築」を掲げ、地域コミュニティを基本としたまちづ

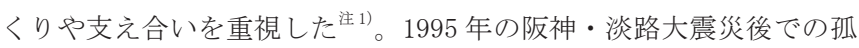
独死の実態や、2004 年の中越地震後の旧村単位での復興の取り組み といった過去の教訓からも、地域コミュニティを重視する復興が多 くの自治体で試みられることになった。

「コミュニティ」注2) という言葉が我が国で頻繁に用いられるよう になったのは、1970 年代に国が押し進めたコミュニティ政策以後と 言われている。それまでの地域社会が崩壊し始めたことが背景とし てあり、象徴的な期待概念として導入された。一方で、明治期以降、 日本には町内会・自治会と呼ばれる地区組織が存在してきた。マッ キーバーによる、人間生活そのもののコミュニティに対する、特殊 的な共同関心を持つ組織としてのアソシエーションの存在について の考察を援用し、岩崎ら ${ }^{4)}$ は町内をコミュニティ、町内会を住むこ とを縁起として形成されるアソシエーション「住縁アソシエーショ ン」として捉え、明確にその位置づけを区別している。東日本大震 災の復興で期待された地域コミュニティの主体も実態的な組織体で
はない町内的なものというよりも、その組織体としての町内会・自 治会だったと考えられる。現に、復興においては、事業主体である 自治体によって、既存のコミュニティの中にどのように新しい移転 地や災害公営住宅を立地させるかといったことだけでなく、そのコ ミュニティとの関係性をいかに保つか、新しい住宅や住宅地の内部 でのコミュニティをどのように醸成するかといった「アソシエーショ ン」としての組織体の創造・維持に関することも検討された。

現代につらなる町内会・自治会の変遷について、吉原 ${ }^{5)}$ は、戦後 の論議は「近代化」論と「文化型」論が相互否定的に交差してきた ことを指摘し、いずれの立場からも一方的に強調するものではなく、 町内会は戦前から戦中そして戦後と日本資本主義の発展のなかで、 その時々の地域社会の課題にリンクした役割を担ってきたと述べて いる。鳥越 ${ }^{6)}$ は、明治初期、江戸期から続いている生活上の地区単 位としての部落や町内は私的な生活組織となったが、戦後 GHQ に解 体された後も、日常生活にとって不可欠のものとして住民組織が存 在し、現在まで存続してきたことを指摘している。被災地の町内会・ 自治会の中には、近代以前の集落の契約講の名残を残寸ものも存在 しており、近代的な組織と近代以前の古層を下敷きとした組織が混 在しているのが、震災以前の状況であった。東日本大震災からの復 興は、そのような近代以前からの歴史を引き継ぐ場所に、近代的な

\footnotetext{
*1 東北大学大学院工学研究科都市 $\cdot$ 建築学専攻 准教授 $\cdot$ 博士 (工学)

Assoc. Prof., Dept. of Architecture and Building Science, Tohoku Univ., Dr.Eng.

*2 日本設計 修士(工学)

*3 東北大学大学院工学研究科都市 ·建築学専攻 教授 · 博士 (工学) 
技術を元に確立されてきた「近代復興」注3) の枠組みによる復興事業 やコミュニティの概念が適用されたものと言える。

また、町内会等地区組織は、地域コミュニティの活動を支える重 要な役割を担い、防災の視点から協働のベースをなすものとしても

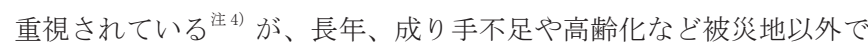
もその存続に課題があることが指摘されている注5)。特に、仙台市近 郊以外の東北地方の多くは、震災以前より人口減少、高齢化が進ん でいた注6)。復興事業において、住民の日常生活を支えるものとして 期待されている地域コミュニティは、すでに弱体化しつつあったと 言える。

\section{2. 研究の位置付け}

災害後の地域コミュニティの変容を扱った論文として、阪神・淡 路大震災後、大都市部とは異なる復興を遂げた淡路市の農漁村地域 を対象に、山崎 ${ }^{10)}$ は中心部としてふさわしい復興が目指された富島 地区と自治会単位で復興が行われた仮屋地区の比較から、復興事業 による空間の変容が近隣関係に影響を与えたことを示し、大上ら ${ }^{11)}$ は、旧津名町志筑地区において、震災前後の向三軒両隣、隣保、自 治会（町内会）という範囲ごとのコミュニティの変容を交流の実態 から分析している。このように自治会をコミュニティの単位とし、 その中での関係性について明らかにした研究が行われている。

東日本大震災被災地での集落やコミュニティと復興との関係につ いては、歴史の分野で特定の地域についての歴史的経過を含めた詳 細な特徵把握が行われているが ${ }^{12,13)}$ 、復興に長期間を有したことも あり、住民を主体としたコミュニティの変容については十分に明ら かになっていない。

また、地域運営組織とその運営方法を扱った研究として、高嶋ら 14) は、仙台市の二地区を対象に町内会の組織体制を示し、それぞれ の運営方法が住民の意識に対応している様子を分析した。旧来型の 安定的な組織形態と課題対応型・自由参加型の機動的・柔軟的シス テムを住民特性を踏まえながら組み合わせて行くことが地域マネジ メントシステムの観点からは重要であることを指摘している。

このように、平時の地域運営組織の体制が住民一与える影響に関 する研究は存在するが、震災以降の大きな変化の中でそのような視 点から地域コミュニティを論じたものは見られない。

\section{3. 研究の目的}

本研究では、東日本大震災被苂地で従前地区を重視しながら住宅 復興事業に取り組んだ一自治体を対象とし、地震と津波による被害 と移転を伴う復興事業を行った際の既存地域コミュニティの変化の 実態と、地域コミュニティがその被害から回復するにあたって、働 いていた要因を明らかにする。回復状況の指標として、地区イベン トに着目して、分析を行う。

本研究では、町内にあたるものを地域コミュニティ、町内会・自 治会にあたるものを地区組織として、用語を統一寸る。地区組織は 行政区など公的に設定された範囲で組織される主体とする。

\section{2. 研究概要}

\section{1. 調査対象}

\section{(1) 調査対象の選定}

宮城県七ヶ浜町を調查対象とする。七ヶ浜町は、宮城県岩沼市と 同様に早期に住宅復興事業を完了した自治体である（災害公営住宅
事業および防災集団移転促進事業がいずれも 2015 年度までに完了し ている)。加えて、復興の主要事業の設計者をプロポーザルにより選 定しており、空間の質についても配慮して事業を行なった。このよ うに、地域コミュティの復興に大きな影響を与えると考えられるス ピードと空間の質という両方を実現した自治体の中で、実際の地域 コミュニティの回復状況に地区組織が与える影響をみることが重要 であると考え対象として選定した。

\section{(2) 七ヶ浜町の概要}

七ヶ浜町は仙台市近郊の半島状で中央が丘陵となった半径 $2.5 \mathrm{~km}$ のエリアを町域としている。町名の由来ともなった太平洋から塩釜 湾に面する七つの集落の歴史は古く、漁業を生活の糧としてきた住 民も少なくなかったが、近年は減少をみせている。また、東北初の

\section{Table 1 Survey method} 調查概要

\begin{tabular}{|c|c|c|}
\hline $\begin{array}{l}\text { Method } \\
\text { 調査方法 }\end{array}$ & \begin{tabular}{|l|} 
Target \\
対象
\end{tabular} & $\begin{array}{l}\text { Contents } \\
\text { 調査内容 }\end{array}$ \\
\hline \multicolumn{2}{|c|}{$\begin{array}{l}\text { Literature survey } \\
\text { 文献調査 }\end{array}$} & $\begin{array}{l}\text { Town record book, Statistics, Administrative documents etc. } \\
\text { · 七ヶ浜町誌、統計書、行政提供資料等 } \\
\text { Grasping residential area with } 1 / 2500 \text { topographic maps } \\
\text { from } 1912 \text { to } 2003 \\
\cdot 1912 \sim 2003 \text { 年の } 1 / 2500 \text { 地形図による居住域形成の把握 }\end{array}$ \\
\hline \multirow[t]{2}{*}{$\begin{array}{l}\text { Interview } \\
\text { ヒアリング } \\
\text { 調査 }\end{array}$} & $\begin{array}{l}\text { Community leader } \\
\text { 地区長 } \\
\text { (公民分館が被災し } \\
\text { た } 7 \text { 地区) - }\end{array}$ & $\begin{array}{l}\text { Outline of community organization } \\
\text { ·地区組織の概要 } \\
\text { Composition of Committee, Board and Event organization } \\
\text { ·役員会、評議員会、イベント実行組織の構成 } \\
\text { Age, gendend, work history and residences of committee } \\
\text { members } \\
\text { ·役員の年齢、性別、職暦、従前 / 現在の居住地 } \\
\text { Distribution and households of Tonari-gumi } \\
\text { ·従前 / 現在の隣組の分布、各組の世帯数 }\end{array}$ \\
\hline & \begin{tabular}{|l|}
$\begin{array}{l}\text { Administrative staff } \\
\text { 行政職員 }\end{array}$ \\
\end{tabular} & $\begin{array}{l}\text { Position of each community association } \\
\text { · 各地区組織の位置付け }\end{array}$ \\
\hline
\end{tabular}

Table 2 The damage of target by GEJE and the number of household 調査対象地の被災状況と世帯数注 7$)$

\begin{tabular}{|c|c|c|c|c|c|}
\hline & \multicolumn{2}{|c|}{$\begin{array}{l}\text { Household } \\
\text { 世帯数 (世帯) }\end{array}$} & \multirow{2}{*}{\begin{tabular}{|c} 
Completely \\
destoryed \\
全壞 \\
(世带)
\end{tabular}} & \multirow{2}{*}{$\begin{array}{c}\text { Large-scale } \\
\text { destroyed } \\
\text { 大規模半壞 } \\
\text { (世帯) }\end{array}$} & \multirow{2}{*}{$\begin{array}{c}\text { Damage } \\
\text { rate } \\
\text { 被害率 } \\
\text { (\%) }\end{array}$} \\
\hline & 2010 & 2015 & & & \\
\hline 菖蒲田浜 Shobutahama & 487 & 381 & 334 & 31 & 63.4 \\
\hline 代ヶ崎浜 Yogasakihama & 240 & 203 & 67 & 70 & 51.9 \\
\hline 花渕浜 Hanabuchihama & 443 & 378 & 170 & 48 & 49.3 \\
\hline 吉田浜 Yoshidahama & 272 & 252 & 26 & 7 & 11.5 \\
\hline 松ヶ浜 Matsugahama & 629 & 591 & 53 & 8 & 10.2 \\
\hline 要害御林 Yogai-Ohayashi & 308 & 328 & 4 & 24 & 9.3 \\
\hline 湊浜 Minatohama & 217 & 214 & 9 & 7 & 7.4 \\
\hline 東宮浜 Toguhama & 256 & 262 & 1 & 13 & 5.2 \\
\hline 遠山 Toyama & 1,145 & 1,156 & 8 & 19 & 2.5 \\
\hline 亦楽 Ekiraku & 249 & 294 & 3 & 1 & 1.5 \\
\hline 汐見台南 Shiomidai-minami & 658 & 677 & 3 & 4 & 1.0 \\
\hline 境山 Sakaiyama & 638 & 678 & 4 & 0 & 0.7 \\
\hline 汐見台 Shiomidai & 1,034 & 1,034 & 1 & 1 & 0.2 \\
\hline
\end{tabular}

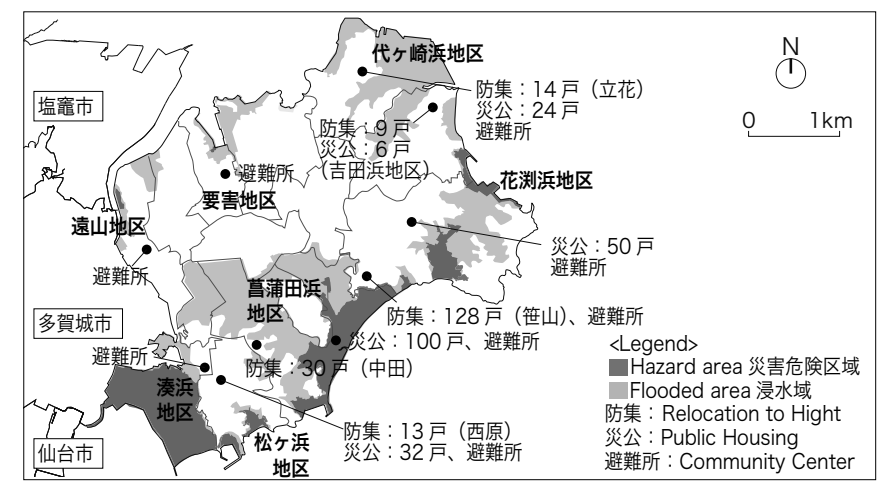

Fig. 1 The site of reconstruction projetcts related housing recovery 
海水浴場である菖蒲田海水浴場は町外からも多くの人が訪れる保養 地でもあった。丘陵部の高台には、町の公共施設が集積するとともに、 戦後以降に整備された複数の住宅地が連続している。七ヶ浜町には 13 の行政区が存在するが、各地区ごとに地形的特徵や成り立ちが異 なっている。そのため、町では従前地区を重視した復興を目指した。

\section{2. 調査概要}

Table 1 に調查概要を示す。地域拠点施設である公民分館が被災し た 7 地区の地区長に対するヒアリングにより各地区の主な情報を把 握した。ヒアリングは、2016 年に実施し、それぞれの地区ごとに複 数回行った。さらに、町全体の概要を知るために、行政職員へのヒ アリングを行った。町の基本情報や統計データ、地理情報、復興関 係データについては、各種文献から情報を得た。

\section{3. 研究方法}

本論文は、次のような構成で研究を進めた。3 章で七ヶ浜町の復興 事業と地区イベント、特に夏祭りの状況について確認する。4 章で震 災以前の各地区組織の構成を、特に役員会とイベント組織に着目し て分析する。 5 章では、隣組と役員に着目して震災前後の地区の変化 を確認し、それらと 3 章で見た夏祭りの再開状況から地区の回復状 況を分析する。

\section{3. 七ヶ浜町の住まいと地域の復興}

\section{1. 七ヶ浜町の被害}

七ヶ浜町では、太平洋側に位置する菖蒲田浜地区、花㴊浜地区、代ヶ 崎浜地区の 3 地区を中心に大きな被害を受けた（Table 2)。震源地 方向に開かれた約 $2 \mathrm{~km}$ の海岸を持つ菖蒲田浜地区は、最も被害が大 きく、63. 4\% の住宅が全壊・大規模半壊となっている。七ヶ浜町の各 地区には公民分館と呼ばれる地域活動の拠点施設が設けられていた。 この公民分館も住宅と同様に津波に流されたり、地震の被害を受け たりして、7 地区で今後の継続利用ができない状態となった。

\section{2. 住まいとコミュニティに関わる復興事業}

東日本大震災からの復興では、災害公営住宅事業、防災集団移転 促進事業（以下、防集事業）、土地区画整理事業（以下、区画事業） などが住宅復興の主な施策として取り組まれた。七ヶ浜町では、災 害公営住宅 212 戸、防集事業 194 戸、区画事業 171 戸を整備してい

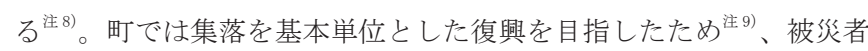
が従前住んでいた各地区で新しい住まいを取得できるように、それ ぞれの敷地が選定された（Fig. 1)。災害公営住宅は、比較的規模の 大きい菖蒲田浜地区、花㴊浜地区、代ヶ崎浜地区では RC 造、規模の 小さい松ヶ浜地区、吉田浜地区では木造によって建設された。防集 事業住宅地で最も大きい笹山地区は花㴊浜地区内の菖蒲田浜地区と の境界に位置し、両地区から入居が行われた。菖蒲田浜地区は、他 に1 所の防集事業住宅地が設けられ、分散する形となった。代ヶ 崎浜地区、松ヶ浜地区、吉田浜地区では災害公営住宅に隣接して防 集事業住宅地が設けられた。

また、公民分館が被災した 7 地区と新しく建設された笹山地区の 地区拠点施設として、地区避難所が建設された。これは、公民分館 の担ってきたコミュニティセンターとしての役割に、災害時の避難 所機能を合わせ持たせたものである ${ }^{\text {ia } 10)}$ 。災害公営住宅が建設された 菖蒲田浜地区、花㴊浜地区、代ヶ崎浜地区、松ヶ浜地区では災害公 営住宅に隣接・近接して建設された。遠山地区では元の敷地、湊浜
地区、要害・御林地区では地区内の新たな敷地に建設された。地区 拠点施設が被災すると、災害後の活動拠点を失うことになり、地域 コミュニティに与える影響が大きいと考えられる。そのため、次節 からの分析はこの 7 地区を対象とした。

\section{3. 復興事業と夏祭りの再開}

地域の復興実態を把握するために、イベントの再開状況を確認し た。震災前のイベントとしては、各地区で行う夏祭りや文化祭、新 年の集い、高齢者サロン、寺社の祭礼といったものや、町が主催す る地区対抗のスポーツ大会などが行われていた。ここでは、全ての 地区で主なものとしてあげられていた夏祭り注 ${ }^{11}$ を対象とし、その 実施と組織体制を扱うこととする。

Table 3 に夏祭りの実施状況と復興事業の進捗を示す。各地区の主 要な復興事業（防集事業・災害公営住宅事業、地区避難所）は 2015 年度までに完了している。夏祭りの再開状況を大きく左右するもの として、被害率が考えられる。被害率が $63.4 \%$ と最も高かった菖蒲 田浜地区では、2016 年においても夏祭りが再開されていない注12)。し かし、花㴊浜地区と代ヶ崎浜地区を比較すると、被害率は代ヶ崎浜 地区の方が高いにも関わらず、花㴊浜地区よりも 4 年早く夏祭りを 再開している。このことから、イベントの再開状況は、被害の大き さのみによって説明することはできない。花渕浜地区は災害公営住 宅と地区避難所が建設完了した翌年に再開しており、拠点としての 場所の存在が影響したことが推察される。

Table 3 Summer festival inplementation and the progress of reconstruction 夏祭りの実施状況と復興事業の進捗注 ${ }^{13}$

\begin{tabular}{|c|c|c|c|c|c|c|c|c|c|}
\hline & \multicolumn{5}{|c|}{$\begin{array}{c}\text { Summer festival } \\
\text { implementation } \\
\text { 夏祭りの実施状況 } \\
\text { (年) }\end{array}$} & \multirow{2}{*}{$\begin{array}{c}\text { Damage } \\
\text { rate } \\
\text { 被害 } \\
\text { 率 } \\
(\%)\end{array}$} & \multicolumn{3}{|c|}{$\begin{array}{l}\text { Progress of reconstruction } \\
\text { (completion date) } \\
\text { 復興事業の進渉 (完了年月) }\end{array}$} \\
\hline & 2012 & 2013 & 2014 & 2015 & 2016 & & $\begin{array}{l}\text { Relocation } \\
\text { 防集事業 }\end{array}$ & $\begin{array}{l}\text { Disaster public } \\
\text { housing } \\
\text { 災害公営住宅 }\end{array}$ & $\begin{array}{l}\text { Facilities for } \\
\text { community } \\
\text { 地域避難所 }\end{array}$ \\
\hline $\begin{array}{l}\text { Minat } \\
\text { 湊浜 }\end{array}$ & 0 & 0 & 0 & 0 & 0 & 7.4 & - & - & $2015 / 1$ \\
\hline $\begin{array}{l}\text { Matsugahama } \\
\text { 松ヶ浜 }\end{array}$ & $x$ & 0 & 0 & 0 & O & 10.2 & $2014 / 3$ & $2015 / 3$ & $2015 / 2$ \\
\hline $\begin{array}{l}\text { Shobutahama } \\
\text { 菖蒲田浜 }\end{array}$ & $\times$ & $\times$ & $x$ & $x$ & $x$ & 63.4 & $\begin{array}{c}2014 / 6 \\
\text { (中田) }\end{array}$ & $2015 / 10$ & $2015 / 7$ \\
\hline $\begin{array}{l}\text { lanabuchihama } \\
\text { 花渕浜 }\end{array}$ & $x$ & $x$ & $x$ & $x$ & 0 & 9.3 & $\begin{array}{c}2015 / 5 \\
\text { (笹山) }\end{array}$ & $2015 / 12$ & $2015 / 11$ \\
\hline $\begin{array}{l}\text { Yogasakihama } \\
\text { 代ヶ崎浜 }\end{array}$ & 0 & 0 & $\bigcirc$ & 0 & 0 & 51.9 & $2014 / 9$ & $2015 / 12$ & $2015 / 5$ \\
\hline $\begin{array}{l}\text { Yogai-Ohanashi } \\
\text { 要害御林 }\end{array}$ & O & $\bigcirc$ & $\bigcirc$ & O & 0 & 9.3 & - & - & $2015 / 8$ \\
\hline $\begin{array}{l}\text { Toyama } \\
\text { 遠山 } \\
\end{array}$ & 0 & 0 & 0 & 0 & 0 & 2.5 & - & - & 2014 \\
\hline
\end{tabular}
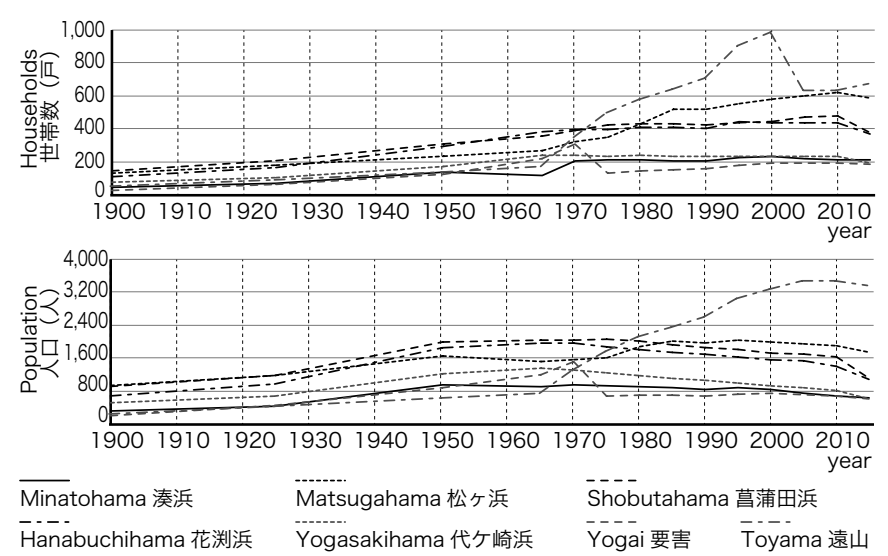

Fig. 2 The transition of households and the population in each district

各地区の世帯と人口の変遷 


\section{4. 小括}

七ヶ浜町では、従前地区を中心として復興事業に取り組み、住宅 や宅地そのものだけでなく、地区拠点施設である地区避難所の建設 も行った。一方で、夏祭りは災害公営住宅や地区避難所が建設され たにもかかわらず、再開できていない地区があった。これは、物理 的な環境の復興だけでは、地域コミュニティでの活動を再開するこ とは難しく、むしろその活動主体となる地区組織の状況が影響して いると考えられる。

\section{4. 地区組織の構成}

前章から、地域コミュニティの復興には、地区組織の状況が影響 することが推察される。そこで、ここでは地区組織の詳細について みていく。

\section{1. 地区の人口と世帯数}

Fig. 2 に各地区の震災前までの世帯と人口の変遷を示す。戦後に宅 地開発が行われた遠山地区の人口が突出して多く、ついで松ヶ浜地 区、花㴊浜地区、菖蒲田浜地区が 1,600 人前後、代ヶ崎浜地区、湊 浜地区、要害地区が 800 人前後となっている。世帯数を見ると、遠 山地区が 2000 年以降世帯数を大きく減らし、松ヶ浜地区とほぼ同規 模で 600 世帯前後、花㴊浜地区、菖蒲田浜地区が約 400 世帯、代ヶ 崎浜地区、湊浜地区、要害地区が約 200 世帯となっている。

\section{2. 地区組織}

Table 4 に七ヶ浜町における地区組織を(1) 近隣住戸、(2) 行政地 区、（3）町の各スケールで分類し、その役割を示す。近隣住戸単位で は隣組が形成され、この上部組織として地区活動を企画実行する行 政地区による各組織が存在する。行政地区組織は町との連携の役割 も担っている ${ }^{\text {ì } 14)}$ 。七ヶ浜町ではこの行政地区を地域コミュニティの 単位として、復興計画の立案などが行われた。

\section{3. 役員会の構成員}

Table 5 に各地区から聞き取った震災以前までの役員会を構成する 役員の役職とその位置付けを示す。位置付けは、(1)充て職/非充て 職、(2)上部組織の有無、(3)任命者の有無で分類した。分類 I (評議員、 庶務会計、地区長、幹事、顧問)、II (区長) は役員会の構成員とし て個人が直接選出されるのに対し、分類III（婦人会、老人会、消防団、 婦人防火クラブ、安全協会、防火防災防犯）、IV（公民分館運営委員会、 環境美化推進員、民生委員）は充て職であり、町単位の上部組織を
持つという特徵を持っている。

Table 6 に、Table 5 の分類に沿ってそれぞれの人数割合を示す。

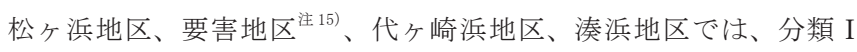
の役員が過半数を超えており、分類III、IVの割合が低い。要害地区、 代ヶ崎浜地区、湊浜地区は、Fig. 2 において、1900 年以降、世帯・

Table 4 Roles of associations for a community 地域に関わる組織と役割

\begin{tabular}{|c|c|c|c|}
\hline \begin{tabular}{|l} 
Unit \\
単位
\end{tabular} & \begin{tabular}{|l} 
Neighbourhood \\
(1) 近隣住戸
\end{tabular} & \begin{tabular}{|l} 
Administrative district \\
(2) 行政地区
\end{tabular} & $\begin{array}{l}\text { Municipality } \\
\text { (3) 町 }\end{array}$ \\
\hline \begin{tabular}{|l|}
$\begin{array}{l}\text { Association } \\
\text { 組織 }\end{array}$ \\
\end{tabular} & \begin{tabular}{|l} 
"Tonari-gumi" \\
隣組
\end{tabular} & $\begin{array}{l}\text { Committee/Board/ } \\
\text { Event organization } \\
\text { 役員会/評議委員会/イ } \\
\text { ベント組織 }\end{array}$ & $\begin{array}{l}\text { Women's association/Community } \\
\text { center managaement committee etc } \\
\text { 婦人会/ 公民分館運営委 } \\
\text { 員会等 }\end{array}$ \\
\hline \begin{tabular}{|l} 
Main roles \\
主な役割
\end{tabular} & $\begin{array}{l}\text { Circulation board } \\
\text { exchange/Collection of } \\
\text { ward expenses } \\
\text { 回覽を回す / 区費の雀収 }\end{array}$ & $\begin{array}{l}\text { Planning and execution } \\
\text { of community activities / } \\
\text { Cooperation with town } \\
\text { 地区活動の企画実行 / } \\
\text { 町との連携 }\end{array}$ & $\begin{array}{l}\text { Achieving the goals of each } \\
\text { organization (fire prevention } \\
\text { training, etc.) } \\
\text { 各団体の目的の達成（防 } \\
\text { 火訓練等） }\end{array}$ \\
\hline
\end{tabular}

Table 5 Positions of commitee members 役員の役職と位置付け

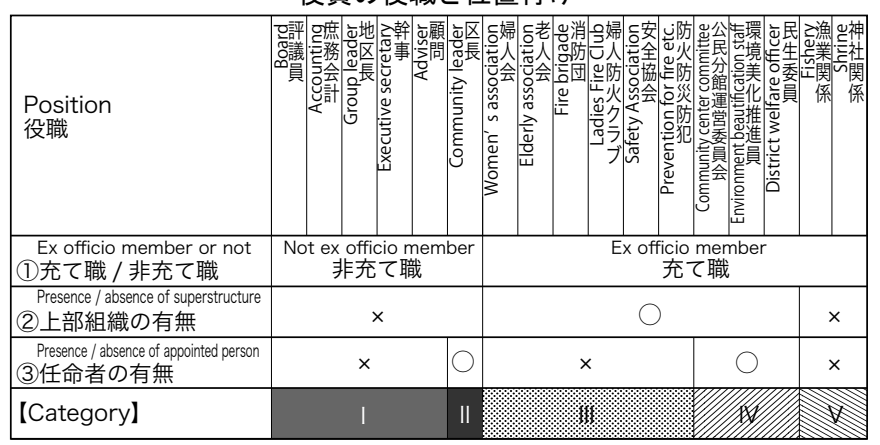

Table 6 The number and the rate of member in each cotegory 各分類の役員の人数と割合

\begin{tabular}{|c|c|c|c|c|c|c|}
\hline District & I & II & III & IV & V & Total \\
\hline $\begin{array}{l}\text { Matsugahama } \\
\text { 松ヶ港 }\end{array}$ & 17 人 (85\%) & 3 人 (15\%) & 0人 (0\%) & O人 (0\%) & O人 (0\%) & 20 人 \\
\hline \begin{tabular}{|l} 
Yogai \\
要害 \\
\end{tabular} & 10 人 (84\%) & 1 人 (8\%) & O人 (0\%) & 1 人 (8\%) & O人 (0\%) & 12 人 \\
\hline $\begin{array}{l}\text { Yogasakihama } \\
\text { 代ヶ崎浜 } \\
\end{array}$ & 9 人 (75\%) & 3 人 (25\%) & 0人 (0\%) & 0人 (0\%) & 0人 (0\%) & 12 人 \\
\hline $\begin{array}{l}\text { Minatohahama } \\
\text { 湊浜 } \\
\end{array}$ & 11 人 (55\%) & 1 人 (5\%) & O人 (0\%) & 3人 (15\%) & 5 人 (25\%) & 20 人 \\
\hline \begin{tabular}{|l|} 
Hanabuchihama \\
花渕浜 \\
\end{tabular} & 12 人 (52\%) & 3人 (13\%) & 5 人 (22\%) & 3 人 (13\%) & 0人 (0\%) & 23 人 \\
\hline $\begin{array}{l}\text { Shobutahama } \\
\text { 菖浦田浜 }\end{array}$ & 9人 (39\%) & 3 人 (13\%) & 7 人 (30\%) & 2 人 (9\%) & 2 人 (9\%) & 23 人 \\
\hline $\begin{array}{l}\text { Toyama } \\
\text { 遠山 } \\
\end{array}$ & 4人 (21\%) & 5 人 (26\%) & 0人 (0\%) & 10 人 (53\%) & 0人 (0\%) & 19 人 \\
\hline
\end{tabular}

\begin{tabular}{|c|c|c|c|c|c|c|c|}
\hline & Togasakihama 代ヶ崎浜 & Yogai 要害 & Shobutahama 菖蒲田浜 & Hanabuchihama 花渕浜 & Matsugahama 松ヶ浜 & Minatohama 湊浜 & Toyama 遠山 \\
\hline 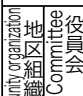 & 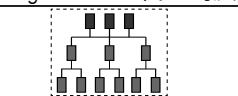 & 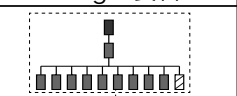 & 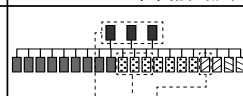 & a & ng & 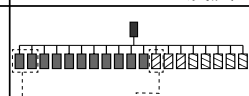 & 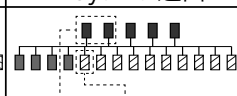 \\
\hline 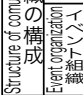 & 買 & 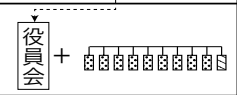 & 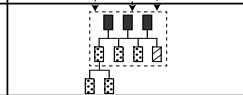 & 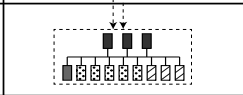 & 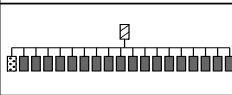 & 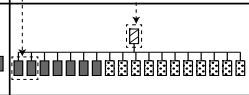 & 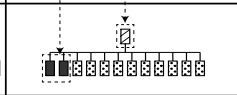 \\
\hline 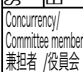 & 12人/12人(100.0\%) & 12人/12人(100.0\%) & 7 人/23人 $(30.4 \%)$ & 12人/23人(52.2\%) & 0人/20人(0.0\%) & 3 人/20人(15.0\%) & 3 人/19人(15.8\%) \\
\hline 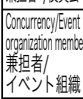 & 12人/22人(54.5\%) & 12人/22人(54.5\%) & 7人/9人(77.8\%) & 12人/12人(100.0\%) & 0人/20人(0.0\%) & 3 人/19人(15.8\%) & 3 人/13人(23.1\%) \\
\hline 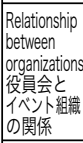 & $\begin{array}{c}\text { Event or } \\
\text { 个ベу } \\
\text { Comn } \\
\text { C彳 } \\
\end{array}$ & $\begin{array}{l}\text { anization } \\
\text { 卜 組織 } \\
\text { nittee } \\
\text { 会 } \\
\end{array}$ & 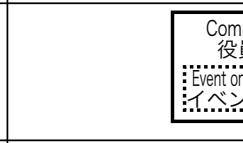 & 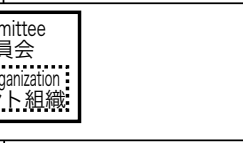 & & $\begin{aligned} \text { Independence } \\
\text { ormmittee } \\
\text { or division of labor }\end{aligned}$ & 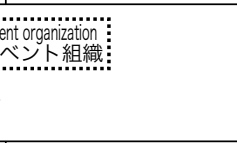 \\
\hline 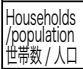 & 240 戸 $/ 851$ 人 & 203 戸 $/ 702$ 人 & 487 戸 / 1,664人 & 442戸/1,431人 & 629 戸 /1,935人 & 217 戸 $/ 701$ 人 & 1,145戸 /3,504人 \\
\hline
\end{tabular}

Fig. 3 The composition of committee and relationship with event organization

役員会の構成とイベント組織との関係 
人口は全体として大きな増減が見られず、現在の世帯・人口規模が 約 200 戸であることが共通している。菖蒲田浜地区、花㴊浜地区は、 分類IIIを役員としている点で他の地区と異なる。また、2 地区とも 世帯数が 2005 年まで増加傾向にあり、約 450 戸である。遠山地区で は、分類IVが役員に多く含まれる。他の地区にはみられない、評議 員会も維持しており、役員会の構成員と重ならないようにしている。 遠山地区は前述のとおり、戦後人口が急激に増加し、現在の世帯数・ 人口も他地区と比較して大きいことから、評議員会を置くことで地 区運営に参加する主体を増やしていることが考えられる。

\section{4. 役員会とイベント組織の関係}

Fig. 3 に役員会の構成とイベント組織（夏祭りのための組織）との 関係を示す。

役員会の構成をみると、代ヶ崎浜地区では区長 3 人とその下の 3 つの組織体から成っている。これらは契約講の名残として存在する 「地区会」であり、代ヶ崎浜地区内の 3 地区（谷地地区、西地区、清 水地区）にそれぞれ存在する。代ヶ崎浜地区は七ヶ浜町の中でも古 くから集落が形成されていた地区であり、その居住域が固定的に維 持されていることが考えられる。それ以外の地区については、区長 の下に役員が同列に並ぶ形となっている。

役員会とイベント組織との関係は、下記の 3 つに分類された。

1）松ヶ浜・湊浜・遠山地区：役員会は複数区長と役員から構成され ている。役職の配分は地区によって異なり、世帯数の多い遠山地区 では分類IVの割合が大きい。イベント組織が役員会から独立してい るため、役員会は地区全体の運営、イベント組織はイベントの企画 と分業しており、役員会に役割が集中しない。夏祭りは震災翌年の
2012 年に再開されている。

2）菖蒲田浜・花㴊浜地区：役員会の構成は1）の地区と同様だが、 イベント組織が一部の役員によって組織されるため、役割が集中寸 る傾向にある。震災後の夏祭りの再開状況をみると、花㴊浜地区は 2016 年に再開しているのに対し、菖蒲田浜地区は 2016 年時点で再開 できていなかった。

3) 代ヶ崎浜・要害地区：役員会に他の構成員を加えてイベント組織 が構成される。役員会が地区全体の運営、イベントの企画ともに中 心となり、大きな役割を担っている。代ヶ崎浜地区は、他地区と異 なり、役員は分類 I ・II のみで、区長と契約講の名残の「地区会」 から構成されている。夏祭りは震災翌年の 2012 年に再開されている。 4. 5. 小括

役員会をみると、地区の世帯・人口に関連して、その構成に違い があるようであった。震災以前までの役員会とイベント組織の状況 をみると、多くが区長の下に各委員が並ぶ体制であるのに対し、代ヶ 崎浜地区では区長の下に地区会が存在し、その中に委員が所属する 形となっていた。イベント組織との関係でみると、役員会と別組織 として存在している場合と、一部の役員で組織される場合、役員会 に他の構成員が加わる場合があることがわかった。特に一部の役員 で組織される場合には、その役員に役割が集中寸る傾向があること がわかった。

\section{5. 震災による地区組織の変化}

前章でみてきた地区組織が震災後にどのように変化したか、被害 率がおおよそ 5 割以上の大規模な被害を受けた、菖蒲田浜地区、花

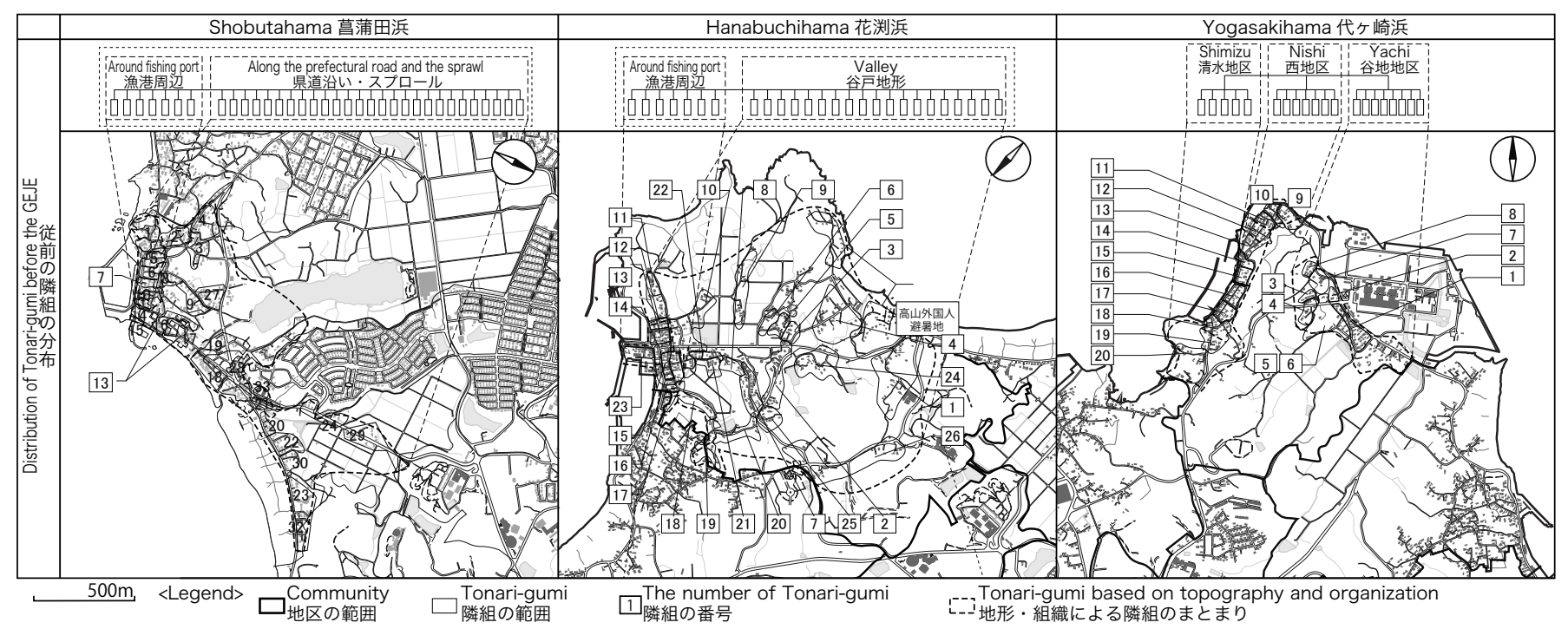

Fig. 4 The distribution of Tonari-gumi before GEJE 従前の隣組の分布

Table 7 The transition of Tonari-gumi before and after GEJE 震災前後の隣組の変化

[Shobutahama 菖蒲田浜地区]

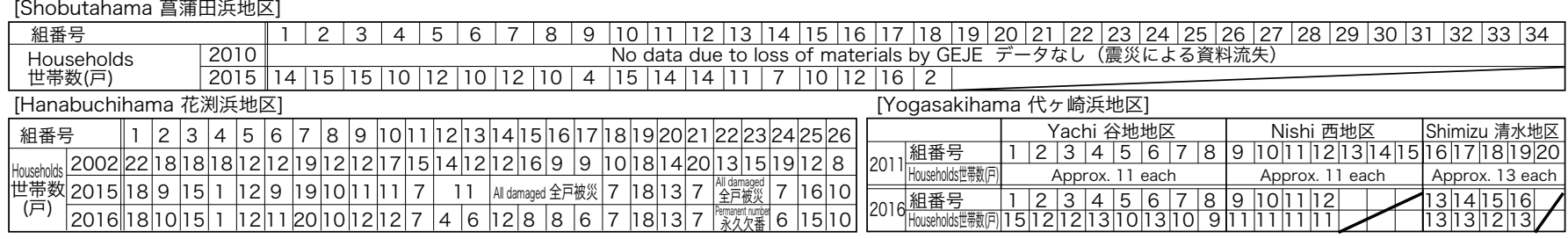


㴊浜地区、代ヶ崎浜地区を対象に、詳細をみていく。

\section{1. 隣組の再編}

Fig. 4 に、菖蒲田浜地区、花㴊浜地区、代ヶ崎浜地区について、震 災前の隣組の分布状況を示す。地形によって編成が異なる様子がみ られるが、各地区共通して、漁港周辺は区画や道路に沿って編成さ れている。一方、菖蒲田浜地区の道路沿いのややスプロール化して いる居住域では、13 組が飛び地となっているなど、入り組んだ編成 がみられる。花㴊浜地区の谷戸地形の居住域は、谷地に延びる道路 に沿った編成となっている。また、代ヶ崎浜地区では、谷地地区、 西地区、清水地区の境界を越える隣組は存在しない注 ${ }^{16)}$ 。

Table 7 に震災前後の隣組の変化を示す。菖蒲田浜地区では、震災 後は被災が小さい隣組も含め全面的に再編している。花㴊浜地区で は、整備された漁港周辺と谷戸に伸びる道路に沿って隣組が編成さ れていたものを、全世帯が被災した 6 組は 2015 年まで機能停止とし、 2016 年総会でそのうち 4 組を災害公営にあて、2 組は永久久番として、 基本的な構成を維持した。代ヶ崎浜地区では、地区会レベルの谷地・ 西・清水地区内で世帯数がほぼ均等になるように隣組を再編してい る。花㴊浜・代ヶ崎浜地区では隣組の構造が保持されたのに対し、 菖蒲田浜地区ではそれが困難であったことが伺える。

多くの復興では、新しくできた住宅地や災害公営住宅でのコミュ ニティに配慮して計画が行われる。さらに、従前からのコミュニティ に配慮する自治体では、従前地区内に住宅地や災害公営住宅を設け ることで、環境の連続性にも配慮している。しかし、地区自体が大 きな被害を受け、さらに従前の土地から移転して住宅再建をする世 帯も少なくはない場合には、その地域コミュニティ自体も従前の状 態から大きく変化せざるをない。復興の核として期待された地域自 体が脆弱化している可能性もあり、そのような実態が示唆された。

\section{2. 役員の変化}

Fig. 5 に世帯の変化と区長の退任に対する対応の様子を示す。役 員の構成員のうち評議員は、会計や書記などの具体的な役割はなく、 役員の居住域の偏りを防ぐために役員のいない隣組から選出される といった特徵があり、本来隣組との関係が強い。評議員と区長の変 化をみると、菖蒲田浜地区では世帯数が減少しても評議員数が変化
しておらず、区長については、2014 年度総会時に 2 名退任した後は 1 名欠員の状態が続き、人材が不足していたことが分かる。花㴊浜地 区では、世帯数の減少に対応して評議員を 5 名減らし、区長につい ては、2012 年度総会時に 2 名が退任、評議員 2 名が新たに区長に就 任した。代ヶ崎浜地区では、災害公営住宅と防集事業住宅地が建設

\begin{tabular}{|c|c|c|}
\hline & $\begin{array}{c}\text { Responding to } \\
\text { household changes } \\
\text { 世帯の変化への対応 }\end{array}$ & $\begin{array}{l}\text { Responding to } \\
\text { retirement of leaders } \\
\text { 区長の退任への対応 } \\
\end{array}$ \\
\hline $\begin{array}{l}\text { Shobutahama } \\
\text { 䓪蒲田㴈 }\end{array}$ & & \\
\hline $\begin{array}{l}\text { Hanabuchihama } \\
\text { 花㴊浜 }\end{array}$ & & \\
\hline $\begin{array}{l}\text { Yogasakihama } \\
\text { 代ヶ崎浜 }\end{array}$ & & \\
\hline
\end{tabular}

Fig. 5 Responding to household changes and retirement of commitee leaders 世帯の変化と区長の退任に対する対応

Table 8 The age and the job of committee members 現在の役員の年齢と就業状況

\begin{tabular}{|c|c|c|c|c|c|c|c|c|c|c|}
\hline & \multirow{2}{*}{$\begin{array}{l}\text { Average } \\
\text { age } \\
\text { 平均 } \\
\text { 年齢 } \\
\text { (歳) }\end{array}$} & \multicolumn{4}{|c|}{\begin{tabular}{|c|}
$\begin{array}{l}\text { Industry where first worked } \\
\text { 新卒時の就業産業 }\end{array}$ \\
\end{tabular}} & \multicolumn{4}{|c|}{\begin{tabular}{|l|} 
Industry in retirement or current \\
退職時もしくは現在の就業産業 \\
\end{tabular}} & \multirow{2}{*}{ Total } \\
\hline & & $\begin{array}{l}\text { Primary } \\
\text { 第一次 }\end{array}$ & $\begin{array}{l}\text { Secondary } \\
\text { 第二次 }\end{array}$ & $\begin{array}{l}\text { Tertiary } \\
\text { 第三次 }\end{array}$ & $\begin{array}{l}\text { Others } \\
\text { 他 }\end{array}$ & \begin{tabular}{|l|} 
Primary \\
第一次
\end{tabular} & $\begin{array}{l}\text { Secondary } \\
\text { 第二次 }\end{array}$ & $\begin{array}{l}\text { Tertiary } \\
\text { 第三次 }\end{array}$ & $\begin{array}{c}\text { Others } \\
\text { 他 }\end{array}$ & \\
\hline \begin{tabular}{|l} 
Shobuta- \\
hama \\
菖蒲田浜 \\
\end{tabular} & 65.4 & 1 人 & 3 人 & 17 人 & 2 人 & 1 人 & 3 人 & 17 人 & 2 人 & 23 人 \\
\hline \begin{tabular}{|l} 
Hanabuchi- \\
hama \\
花㴊浜 \\
\end{tabular} & 65.9 & 1 人 & 2 人 & 13 人 & 1 人 & 1 人 & 2 人 & 13 人 & 1 人 & 17 人 \\
\hline $\begin{array}{l}\text { Yogasaki- } \\
\text { hama } \\
\text { 代ヶ崎浜 } \\
\end{array}$ & 68.1 & $10 人$ & O人 & 3 人 & 0人 & $2 人$ & O人 & 11 人 & O人 & 13 人 \\
\hline
\end{tabular}

Table 9 The residence period of committee members 現在の役員の地区での居住開始時期

\begin{tabular}{|l|c|c|c|c|c|c|}
\hline & Before 1912 & $1912-1946$ & $1946-1964$ & $1964-1982$ & $1982-2003$ & Total \\
\hline $\begin{array}{l}\text { Shobutahama } \\
\text { 菖蒲田浜 }\end{array}$ & 7 人 (30\%) & 11 人 (48\%) & 3 人 (13\%) & 1 人 (4\%) & 1 人 (4\%) & 23 人 \\
\hline $\begin{array}{l}\text { Hanabuchihama } \\
\text { 花㴊浜 }\end{array}$ & 7 人 (41\%) & 6 人 (35\%) & 4 人(24\%) & 0 人 (0\%) & 0 人 (0\%) & 17 人 \\
\hline $\begin{array}{l}\text { Yogasakihama } \\
\text { 代ヶ崎浜 }\end{array}$ & 11 人 (85\%) & 0 人 (0\%) & 0 人 (0\%) & 0 人 (0\%) & 0 人 (0\%) & 13 人 \\
\hline
\end{tabular}

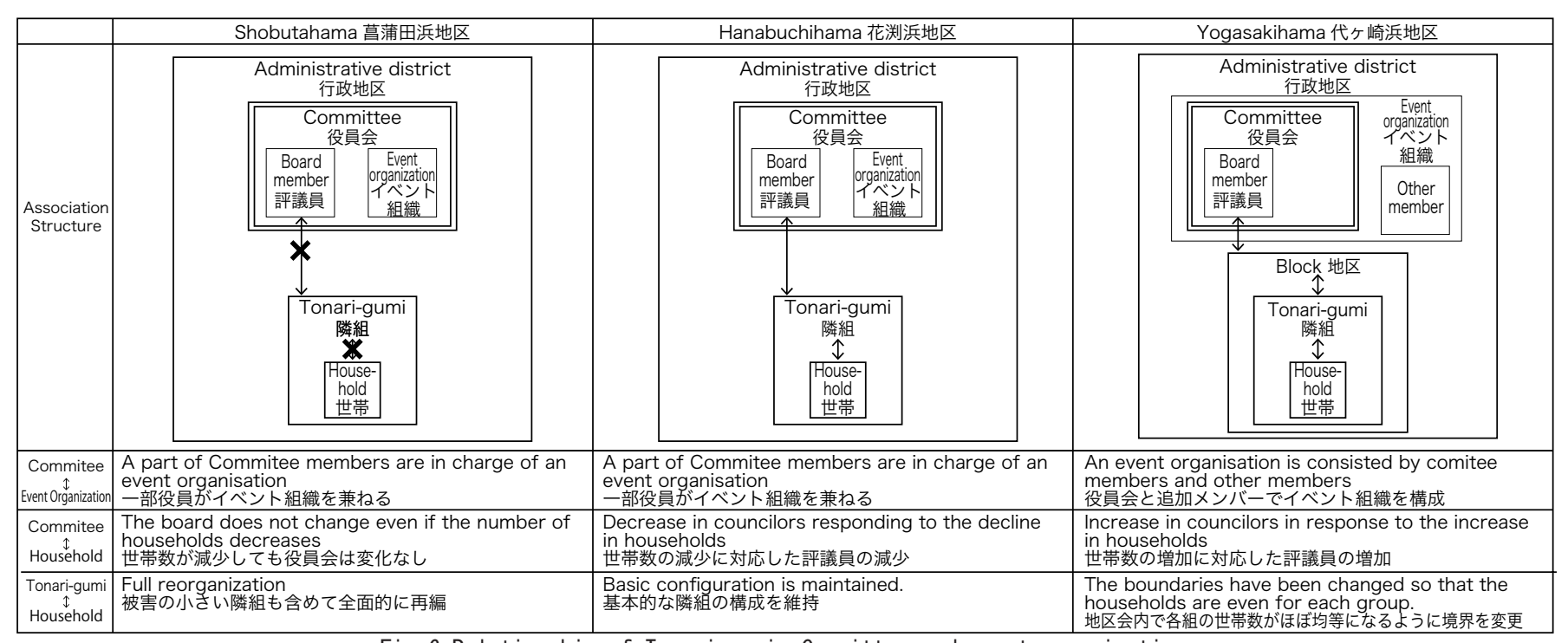

Fig. 6 Relationship of Tonari-gumi, Committee and event organization

隣組 / 役員会 / イベント組織の関係 
された地区の評議員を増やし、区長については、2012 年度総会時に 3 名が退任、地区会の会長 3 名が新たに区長に就任している。

Table 8 に役員の年齢と就業状沉、Table 9 に地区での居住開始時 期を示す。平均年齢は、いずれも 65 歳以上、特に代ヶ崎浜地区は 68.1 歳と高齢となっている。就業産業をみると、菖蒲田浜地区、花 㴊浜地区は新卒時から現在まで第三次産業従事者が多い。一方、代ヶ 崎浜地区は退職時もしくは現在では第三次産業が多いが、新卒時は 第一次産業が多く、元々地域での海苔養殖など漁業に従事している 者が多かった。代ヶ崎浜地区で契約講の名残が強く残っていたのは、 近年まで地区内の多くが漁業に従事していたことが影響していると 考えられる。現在の役員の居住開始時期を見ると、代ヶ崎浜地区で は 1912 年以前に同じ場所に居住していた人数が多いことがみて取れ る。このような要因から代ヶ崎浜地区の役員体制が近代以前のなご りを残寸形で維持されていたと考えられる。

\section{3. 夏祭りの再開と地区組織}

3 章で夕た夏祭りの再開と前節で確認した役員会の体制の変化から 夏祭りの再開と地区組織の関係をみていく（Fig. 6)。

2012 年に夏祭り再開の代ヶ崎浜地区では、役員会に町の下部組織 が加わってイベント組織が構成されることで、役員会とイベント組 織の関係が維持されている。また、代ヶ崎浜地区では、隣組が 3 つ の地区会の中で再編されていることから、地区会と隣組の関係性が 強いと考えられる。多層的な組織のフレームを保持することにより 早期再開に繋がったと考えられる。

花㴊浜地区では、震災後の世帯数の変化に対応して評議員の人数 が減少していることから、世帯は評議員と関係があると考えられる。 また、隣組の基本的な範囲を維持することで、役員会と世帯の関係 を維持していると推察される。この関係が維持されたことと、イ心゙ ント組織が一部役員で構成されており、役員変更の影響は受けるが、 役員会とイベント組織の関係が維持されることによって、住宅再建 などによる地区外一の転居で区長の入れ替わりがありながらも、役 員会・評議員・隣組・世帯の連関が保持され、災害公営住宅や地区 避難所の整備が完了した翌年の 2016 年度に夏祭りを再開することが できたと考えられる。

一方、菖蒲田浜地区では、イベント組織は一部の役員で構成され るため、相互の関係はその役員一の役割の集中によって保たれてお り、特定の役員が変更する影響が大きい。さらに、震災後、世帯数 が大きく減少し、隣組も全面的に再編されているにも関わらず、役 員会の構成が維持されており、評議員数の变化がない。役員会・評 議員・隣組・世帯の連関関係が希薄であり、状況の変化に応じて柔 軟に体制を変更できる状態ではなかったことが伺える。実際、災害 公営住宅や地区避難所の整備完了後の 2016 年時点でも夏祭りが未再 開であった。

\section{4. 小括}

被害規模の大きい 3 地区の詳細をみることで、世帯の増減に合わ せて、元々隣組と関連の深い評議員が増減している場合があること がわかった。役員会の組織体制と夏祭りの再開状況を合わせてみる と、多層的な組織のフレームを保持することで被害に耐えた地区、 一部の役員に役割の重複はみられるが、隣組と連関する評議員の数 を合わせて減らすなどして、できるだけ隣組の枠組み自体を変えず、 役員会組織の下部構造を改変して対応した地区、隣組も全面的に再
編し、また、役員によっては役割の集中が見られ、役員会自体も構 成が維持されていたため、体制を立て直すのに苦労している地区が あることがわかった。

\section{6. 考察と結論}

津波被害にあった一自治体を対象として、住宅復興の基盤となる 従前コミュニティの被害とその後の組織体制の状況をみることで、 災害後の地域コミュニティの回復の様子とその要因を探ってきた。 明らかとなったことは下記の通りである。

(1) 異なる隣組の再編実態 被害にあった地域では隣組の再編が行 われていた。しかし、その再編の様子は地域によって異なっており、 できるだけ元の隣組の枠組みを変えないで対処したところ（花㴊浜 地区)、隣組の上位にある地区会の枠組みを維持し、その中で隣組の 再編を行ったところ (代ヶ崎浜地区)、従前から飛地など地形によら ない隣組が存在し、被災後に被害が小さかったところも含めて全面 的に再編したところ（菖蒲田浜地区）が存在した。

（2）評議員の役割と地区組織体制 役員会の体制として、区長の下 に役員が位置するものと、地区会を設け区長の下に地区長、その下 に評議員を構成している二つの形態が見られた。後者では漁業での 住民間の繋がりが存在しており、地区組織の古層が今でも残ったも のと考えられる。さらに、世帯・隣組の変化に評議員が関係してい る可能性が示唆された。比較的早期に夏祭りが再開できた地区では、 隣組の変化に役員会の一員である評議員の数を対応させて組織を改 変している様子がみてとれた。この役員会と隣組との関係が強固で あるほど、古い時代の形態を今に残していると考えられる注 17)。

（3）役員会の組織体制 役員会とイベント組織の関係にも地区ごとの 違いが見られた。役員会とイベント組織が別組織になっているもの、 一部の役員がイベント組織を担うもの、役員会に他の構成員を加え るものの 3 つがみられたが、特に 2 つの一部の役員がイベント組 織を担う場合は、限られた役員でイベント運営を行う必要があるた め、一部の役員の役割が大きくなりがちである。今回のように災害 で大きな被害を受けた場合には、その役員自身を失う可能性もあり、 その場合に組織の受ける影響が大きい。一方で、代ヶ崎浜地区では 地区会を設けることで、そこで経験を積んだ者が将来的に区長を担 うことになっている。技術的な経験の維持が必要であり、海難事故 などの危険とも常に隣り合わせの漁業という紐帯を元にすることで、 集落内部の経験も受け継ぐことや組織を担う人材を複数育てること を可能とする形態をとり、それが維持されていることが、東日本大 震災の復興でも影響していると推察される。

七ヶ浜町の実態から、世帯と隣組、隣組と評議員、評議員と役員 会が連関しながら地区組織を形成してきたことがわかった。地区の 役員会・評議員・隣組・世帯を連関させた改変を行い、組織のフレー ムを維持することができる体制をとっていた地区においては、人的 な被害が出た後も地域組織を維持し、高台移転や災害公営住宅の入 居などで新たな住まいを得た住民をサポートする受け具としての機 能も発揮している。このような多層的なフレームは合理的であるこ とを目指寸近代的思考というよりは、生業を軸とした近代以前から の形態であることが伺える。一方で、一部の役員が複数の役割を担 うことで維持されている地区組織では、震災によって、人的な被害 
が出た際、大きなダメージを受けていた。

さらに、地区組織というと役員会にのみ着目しがちだが、実際に は世帯に直接関連する隣組の状況と役員会との関係が、地域コミュ ニティの耐力に関係している。近年の災害復興でとりあげられるこ との多い、コミュニティ・レジリエンス注18) の観点からも地区組織 を考えることは重要であると言える。

ただし、地域コミュニティが脆弱だったところは必ずしも震災に よる要因だけで弱体化したのではなく、今回地区組織が維持された ところでも、高齢化の状況から今後の災害時に再び可能になるかは わからない。平時から生活を支える組織として住民と地区組織がど のようなあり方で存在するべきか、改めて考える必要があるだろう。

\section{謝辞}

七ヶ浜町の各行政区長および役員、町職員のみなさまには、調查に ご協力いただき、貴重な情報を提供していただいた。ここに記して、 御礼申し上げる。

なお、本論文は日本建築学会大会学術講演梗概集に発表したデータ 18) を大幅に再構築してまとめ直したものである。

\section{注}

注 1) 文献 $1 、 2$ 。宮城県を例にとると、宮城県震災復興計画において、「被災者 の生活環境の確保」に関して、「地域コミュニティの再構築」が一項目と してあげられている。さらに、宮城県復興住宅計画においては、「これま で住み慣れた地域でのコミュニティ再生、再構築を図るとともに、住民が 中心となった復興を進める」こと、「地域コミュニティを基本とした支え 合う仕組みによる住まい方等を検討する」ことがあげられている。

注 2) デランティ ${ }^{3)}$ は、近代以降の社会学と文化人類学におけるコミュニティ の概念について、テンニースによる伝統を含み込む社交生活を指すものか ら、脱伝統的・市民道徳的な力として提示したデュルケムの定義、コーエ ンが特定の自己認識という観点から行った境界線の構築を基礎とした象徴 的な形態としての位置づけという主要な議論の展開を示した。

注 3）文献 7 において、阪神・淡路大震災を含む、東日本大震災までに確立さ れた災害復興の枠組みを「近代復興」として問題提起した。「国家や産業 界が主導する復興であり、高度経済成長という類をみない社会情勢を背景 にしながら形成されてきた方法論」としている。

注 4）文献 8 。防災の視点から、市民・住民と行政を媒介し、ボランティアも含 めた三者間の協働のベースをなすものとして地域コミュニティが近年重視 されてきており、特に阪神・淡路大震災以降、町内会がその草の根の地域 組織として見直されるようになってきたことが指摘されている。

注 5) 文献 4 より。

注 6) 文献 9 を参考に、2005 年と 2010 年の国勢調査から、岩手・宮城県内市町 村の人口増減と高齢化率を確認したところ、人口増および全国平均より低 い高齢化率であるのは仙台市および仙台市近郊の名取市、岩沼市、多賀城 市、利府町のみであった。

注 7) 2010、2015 年の世帯数は各年 1 月 1 日の住民基本台帳、被害数は 2011 年 10 月 31 日の税務課で発行した罹災証明に基づく。被害率は全壊数と大規 模半壊数の合計を被災時の世帯数で割って算出した。

注 8) 文献 15 より。

注 9）文献16では、七ヶ浜町も対象事例として分析を行った。七ヶ浜町は住民 への丁寧な聞き取りが求められる「防集事業中心型」であり、既存集落の 近傍に防集での宅地整備を行う「差し込み型防集」を目指寸とともに、防 集事業と災害公営住宅事業の事業間の統合を図りながら、内部の检討と住 民会議・WS や広報を段階的に行い、既存集落を基本単位とした復興を目指 したことを示した。

注 10）七ヶ浜町では全13 地区それぞれに公民分館が設置されていた。そのうち、 7 ケ所が地震・津波によって被災を受け、再建されることとなった。再建 にあたっては、生涯学習機能だけでなく、防災機能を新たに付加し、地域 の防災拠点として復興交付金を活用して建設された。

注 11）東北 6 都市の町内会を調查した文献 8 では、会員がある程度参加してい
ると認知される行事は「町内会の総会」、「夏祭り」、「神社祭礼」としてお り、七ヶ浜町だけでなく、「夏祭り」が多くの町内会で主要なイベントで あることが分かる。

注 12）2017 年度以降も菖蒲田浜地区では夏祭りは実施されていない（2020 年 時点)。

注 13） 2016 年の夏祭りの概要を Table10 に示す。参加人数は、準備段階から 閉会まで 30 分ごとに参加状況を平面図にプロットしたデータから、最大 となった参加者数を記載した。内容については、当日の観察と案内チラシ を元にまとめた。出し物以外に、各地区とも夜店も開かれていた。

Table 10 The detail of summer festival in 2016 2016 年度夏祭りの概要

\begin{tabular}{|c|c|c|c|}
\hline & \begin{tabular}{|c|} 
The date \\
開催日
\end{tabular} & $\begin{array}{c}\text { The laergest } \\
\text { number of } \\
\text { paticipants in } \\
\text { each } 30 \mathrm{~min} . \\
30 \text { 分ごとの } \\
\text { 最大参加者数 } \\
\text { (人) }\end{array}$ & $\begin{array}{l}\text { The contents of summer festival } \\
\text { 夏祭りの内容 (出し物) }\end{array}$ \\
\hline \begin{tabular}{|l|}
$\begin{array}{l}\text { Minatohama } \\
\text { 湊浜 }\end{array}$ \\
\end{tabular} & $8 / 6$ & approx. 230 & $\begin{array}{l}\text { Taiko, Bon dance, Lottery etc. } \\
\text { 太鼓、輪踊り、抽選会等 }\end{array}$ \\
\hline $\begin{array}{l}\text { Matsugahama } \\
\text { 松ヶ浜 }\end{array}$ & $8 / 20$ & approx. 300 & $\begin{array}{l}\text { Taiko, Dance, Cheer dance, Bon dance, } \\
\text { Lottery etc. } \\
\text { 太鼓、踊り、チアダンス、輪踊り、抽選会等 }\end{array}$ \\
\hline $\begin{array}{l}\text { Hanabuchihama } \\
\text { 花渕浜 }\end{array}$ & $8 / 6$ & approx. 200 & $\begin{array}{l}\text { Chorus, Musical instrument performance, } \\
\text { Bingo etc. } \\
\text { 合唱、楽器演奏、ビンゴ大会等 }\end{array}$ \\
\hline $\begin{array}{l}\text { Yogasakihama } \\
\text { 代ヶ崎浜 }\end{array}$ & $8 / 6$ & $\begin{array}{l}\text { Unknown due } \\
\text { to data loss }\end{array}$ & $\begin{array}{l}\text { Chorus, Karaoke, Juggling, Dance, Bon } \\
\text { dance etc. } \\
\text { 合唱、カラオケ、ジャグリング、踊り、輪踊り等 }\end{array}$ \\
\hline $\begin{array}{l}\text { Yogai-Ohanashi } \\
\text { Y要害御林 }\end{array}$ & $7 / 30$ & approx. 160 & $\begin{array}{l}\text { Karaoke, Dance, Bon dance, Lottery etc. } \\
\text { カラオケ、踊り、輪踊り、抽選会等 }\end{array}$ \\
\hline $\begin{array}{l}\text { Toyama } \\
\text { 遠山 }\end{array}$ & $8 / 6$ & $\begin{array}{c}\text { over } 200 \\
\text { (Unmeasurable due } \\
\text { to large number) }\end{array}$ & $\begin{array}{l}\text { Taiko, Dance, Cheer dance, Musical } \\
\text { instrument performance, Children's } \\
\text { association event, Lottery etc. } \\
\text { 太鼓、踊り チアダンス、楽器演奏、子ども会イ } \\
\text { ベント、抽選会等 }\end{array}$ \\
\hline
\end{tabular}

注 14）文献 6 において、地域自治会組織の持つ特徴の一つとして、世帯単位制、 地域占拠制、全世帯加入制、包括的機能に並んで、行政末端機能が上げら れている。地域自治会は行政機関から枝分かれしたものから生まれており、 近代化のプロセスにおいて行政と地域自治会との間に役割上の振り子関係 があったことが指摘されている。明治初年から 20 年代までは国家の地方 制御のための地方自治はかなり混乱しており、住民は地方自治とかかわり つつ独自の自立した地域組織をもちつづけなければならず、このころの「歴 史の古い」自治会が行政の末端組織としての役割を決定し、実質的役割か ら補強的役割への変化から、現在のソフトの部分を包括的に担当する形に 落ち着いたとしている。

注 15）要害地区と御林地区は隣接する地区同士で、地区避難所も合同の施設と して建設された。しかし、異なる行政区でありそれぞれが地区組織を持つ。 ここでは、元々公民分館を持っていた要害地区を対象にその地区組織を把 握した。

注 16）文献 6 において、大阪府箕面市の例から、明治 22 年の市制・町村制によっ て区の設置が可能になりその下の組織として組があったこと、近隣をひと まとめにしており隣近所が同じ組に入るのが普通であるが、地区内で移動 したり、分家を作り出したりしたときに組への所属を許してもらった状態 で、地理的に離れたところに住む場合があったことが指摘されている。こ のように世帯を単位として組織化した組・班はそれを構成する世帯の範囲 が変化することでその地理的領域も変化させるということがまま発生して いる。

注 17）文献 6 において、歴史のある自治会は、地域社会そのものが歴史性、個 別性をもつことにより、当該地域固有の役割を担わせられ、組織が複雑 になってくることが指摘されている。特に、その地域固有の「生活の歴史」 を担っているために、組織そのものに歴史性が入り込んでいる場合では、 町内会は複雑な構造を持ち、班など下位組織についての影響力が強い。 さらに、「班」の成立が歴史的に古いところでは、その自律度が高く、後 に行政機関の要請によって生まれた上位の組織の基礎単位となるなどそ の位置づけが大きいことを示している。

注 18）災害への抵抗力で被害を低減する方法ではなく、その復元・回復力（レ ジリエンス）に目を向けるべきだという考え方。歴史的に作り上げられ た脆弱性が災害の地域社会へのインパクトの実相を決めていくとして、 地域を復元・回復していく原動力をその地域に埋め込まれ育まれていっ た文化や社会的資源の中にみることの重要性が社会学などの分野で述心゙ られてきた ${ }^{17)}$ 。 


\section{参考文献}

1) Miyagi Prefecture:Miyagi Prefecture Earthquake Recovery Plan, 2011. 10 宮城県：宮城県震災復興計画, 2011. 10

2) Miyagi Prefecture:Miyagi Prefecture Reconstruction Housing Plan, 2011. 12

宮城県 : 宮城県復興住宅計画, 2011. 12

3) Delanty, G. : Community, NTT Publishing Co., LTD,, 2006 (Japanese version)

ジェラード・ディランティ:コミュニティーグローバル化と社会理論の変容, NTT 出版， 2006

4) Iwasaki, N., et al. : Extended edition Zohoban Chonaikai-no-kenkyu, Ochanomizu Shobo, 2013

岩崎信彦他編：増補版町内会の研究，御茶の水書房，2013

5) Yoshihara, N. :Chiikishakai-to-chiikijuminsoshiki, Yachiyo-shuppan, 1980

吉原直樹：地域社会と地域住民組織 - 戦後自治会への一視点，八千代出版， 1980

6) Torigoe, H. : Chiikijichikai-no-kyenkyu, Minerva Shobo, 1994 鳥越皓之：地域自治会の研究-部落会・町内会・自治会の展開過程, ミネル ヴァ書房， 1994

7) Journal of Architecture and Building Science, No.1647, AIJ, 2013.3 建築雑誌, No. 1647, 日本建築学会, 2013.3

8) Yoshihara, N., et al. : Bosai Community-no-kiso, Ochanomizu Shobo, 2011

吉原直樹編：防災コミュニティの基層 - 東北 6 都市の町内会分析，御茶の水 書房 , 2011

9) Ministry of Land, Infrastructure, Transport and Tourism: White Paper on Land, Infrastructure, Transport and Tourism in Japan, 2010 国土交通省：平成 22 年度国土交通白書, 2010

10) Yamazaki, J. :The Actual Situation of Spatial Formation and Community Transformation after the Earthquake Disaster - In the cases of Toshima district at Hokudan-cho, and Kariya district at Higashiuracho, In Awaji-city, Hyogo prefecture, Journal of Architecture and Planning (Transactions of AIJ), Vol.75, No.649, pp.609-618, 2010.3 (in Japanese)

山崎寿一 : 震災復興事業後の農漁村の空間構成とコミュニティの継承・変 容一兵庫県淡路市北淡町富島地区と東浦町仮屋地区を事例として，日本建 築学会計画系論文集，第 75 巻，第 649 号，pp. 609-618，2010. 3

11) Oue, Y. and Yamazaki, J. :Study on Influence through the Reconstruction Project Focusing on Interannual Transformation of the Former Community - A case study of Shizuki destrict at old Tsuna-cho after the greatHanshin-Awaji earthquake, Journal of Architecture and Planning (Transactions of AIJ), Vol.79, No.695, pp. 113-122, 2014.1 (in Japanese)

大上泰弘，山崎寿一: 淡路地域における従前コミュニティの特質と変容 からみた震災復興事業が与えた影響 - 阪神・淡路大震災後の旧津名町志筑 地区を対象として, 日本建築学会計画系論文集，第 79 巻，第 695 号， pp. 113-122, 2014. 1

12) Aiba, S., et al. : Tsunami-no-aida, Ikirareta-mura, Kajima Institute Publishing Co., Ltd., 2019

饗庭伸ほか：津波のあいだ、生きられた村，鹿島出版会，2019

13) Okamura, K. : "Sanriku-tsunami" to-Shuraku-Saihen, Kajima Institute Publishing Co., Ltd., 2017

岡村健太郎：「三陸津波」と集落再編 - ポスト近代復興に向けて，鹿島出版 会, 2017

14) Takashima, M. , Kochizawa, M. and Ishizaka, K. :Relevance of Inhabitants Characteristics and Method for Administrating Neighborhood - Case study on 2 districts in Sendai city, Journal of Architecture and Planning (Transactions of AIJ), Vol.75, No.655, pp. 2197-2202, 2010.9 (in Japanese)

高嶋みちの，小地沢将之，石坂公一：地区特性と地域運営手法との関連性 一仙台市の 2 地区を事例として, 日本建築学会計画系論文集, 第 75 巻, 第 655 号，pp. 2197-2202，2010.9

15) Shichigahama Town: Shichigahama-machi-no-Jutakufukko-oyobiChiikifukkosesaku-ni-tsuite, 2017.5.23

七ヶ浜町：七ヶ浜町の住宅復興及び地域復興施策について，2017.5.23 (accessed 2020.7.1)
16) Onoda, Y., Kato, Y. and Tsukuda, H. : Implementation of Recovery Plan and Organization Structure of Municipalities - On the reconstruction procedures in Miyagi Prefecture from the Great East Japan Easrthquake, Journal of Architecture and Planning (Transactions of AIJ), Vol.80, No.717, pp. 2523-2531, 2015.11 (in Japanese)

小野田泰明，加藤優一，佃悠：災害復興事業における計画実装と自治体の 組織体制 - 東日本大震災における宮城県の復興事業を対象として，日本建 築学会計画系論文集，第 80 巻，第 717 号, pp. 2523-2531, 2015. 11

17) Urano, M. et al. :Fukko-Community-Ron-Nyumon, Kobundou, 2007 浦野正樹ほか：復興コミュニティ論入門，弘文堂，2007

18) Tsukuda, H., Hasegawa, K. and Onoda, Y. : A Study on Conditions Enabling Local Community to Recover from Great Disasters - Case Study of Damaged Districts from the Great East Japan Earthquake in Shichigahama Town, Miyagi Prefecture, Summaries of Technical Papers of Annual Meeting, Architectural Institute of Japan, Architectural Planning and Design, pp.1173-1174, 2017.7(in Japanese)

佃悠，長谷川京子，小野田泰明：大規模災害後の地域コミュニティの回復 条件に関する研究一宮城県七ヶ浜町の東日本大震災被災地区の調査から，日 本建築学会大会学術講演梗概集，建築計画，pp. 1173-1174, 2017.7

19) Shichigahama town magazine compilation committee: Shichigahama town magazine, 2008 (in Japanese) 七ヶ浜町誌編纂委員会 : 七ヶ浜町誌 - 増補版 -, 2008

20) Onoda, Y. and Tsukuda, H. :New Germination of Japanese housing Complexes - Post-Disaster Public Housing on the Reconstruction from the Great East Japan Earthquake, Shinkenchikusha, 2016 (in Japanese) 小野田泰明，佃悠：集合住宅の新しい文法－東日本大震災復興における災 害公営住宅，新建築社，2016 


\title{
A STUDY ON THE RECOVERY OF LOCAL COMMUNITY AFTER A LARGE DISASTER
}

Case study of damaged areas by the Great East Japan Earthquake in Shichigahama Town, Miyagi Prefecture

\author{
Haruka TSUKUDA ${ }^{* 1}$, Kyoko HASEGAWA ${ }^{* 2}$ and Yasuaki ONODA*3 \\ ${ }^{* 1}$ Assoc. Prof., Dept. of Architecture and Building Science, Tohoku Univ., Dr.Eng. \\ ${ }^{* 2}$ NIHON SEKKEI, M.Eng. \\ ${ }^{*}$ Prof., Dept. of Architecture and Building Science, Tohoku Univ., Dr.Eng.
}

The Great East Japan Earthquake and the tsunami that occurred in March 2011 caused major damage in the Tohoku region. It is implicitly assumed that there is a local community in the reconstruction after the Great East Japan Earthquake, but the local community itself has suffered great damage. The members themselves are residents who are victims of the disaster, and the physical situation in the area has changed significantly due to reconstruction projects such as relocation. Capturing the recovery of the local community itself is also an important perspective for considering the possibility of reconstruction of the disaster victims as individuals and the disaster area. Therefore, the purpose of this paper is to clarify the change of the local community after the damage of the Great East Japan Earthquake and reconstruction projects and the factors for the recovery of the local community.

As a result, firstly, each "Tonari-gumi" as a basic unit of community association was reorganised in a different way for each local community that damaged by GEJE. Secondly, there are two types of the structure of the community committee. One has consisted of chairpersons and committee members under them. The other one is the committee including some blocks "Chiku". The committee members belong to block committees. The latter remains the pre-modern structure based on the fishery community. Furthermore, board members are selected related to households in each local community. It was found that households and community associations have a multi-layered relationship. Finally, the relationship between community committee and event organization is three different types, both are different organizations, the committee including event organization, and all committee members joining event organization. The relationship between the committee and the event organization suggested that the community association may be maintained as an individual rather than as an organizational system. If the personal role is large, if the human damage is caused by the earthquake, the loss of the key person will cause great damage to the community association. On the other hand, community associations that have the organizational framework in cooperation with its subordinate organization was maintained even if human damage occurred. Such a multi-layered frame is considered to be a premodern form centered on livelihood, rather than a modern thinking aiming to be rational.

In conclusion, community association tends to focus only on the committee, but in reality, the situation of Neighboring groups "Tonari-gumi" directly related to households and the relationship with the committee are related to the resilience of the local community. It can be said that it is important to consider community associations from the perspective of community resilience, which is often addressed in recent disaster recovery. However, when the local community was vulnerable, it was not necessarily weakened only by the earthquake. Even if the community association is well maintained this time, it may not be possible to maintain it in future disasters due to aging and so on. It will be necessary to reconsider how the residents and community association should exist as organizations that support daily life. 